\title{
The Effect of Sexual Debut and Health Risk Behaviours on the Baccalaureate Performance of Romanian Adolescents
}

\author{
Csaba Laszlo Degi and Cristina Faludi \\ Faculty of Sociology and Social Work, Babes-Bolyai University
}

\section{Abstract}

Relationship between sexual and health risk behaviours and school success is rarely investigated in Central-East European countries. The present project studies their impact on the results of the compulsory graduation examination, called Baccalaureate, in Romania. In this follow-up analysis 401 graduate high school students were surveyed. We measured scholastic achievement by means of the indicators of promotion and performance in standardized testing. The self-administered School Success Profile questionnaire included items on health-related (smoking, binge drinking, and illicit drug use) and sexual debut behaviours. Descriptive statistics and logistic regression were conducted. Results show that students from rural and deprived communities, those obtaining failing grades in the last semester and involved in an unstable relationship at the sexual debut had significantly increased odds of failure and lower average grades in the final examination, when adjusted for age, sex, religious practice and health status. Within the framework of health education, school educators should not neglect the education for the reproductive health, and health education should accompany the adolescent throughout his/her life.

Key words: emerging adults; school success; sexual debut.

\section{Introduction}

High school is the major formal organization of the life-cycle stage of adolescence, characterized by specific values, norms and routines which play a tremendous role in the individual's intellectual, socio-emotional and behavioural development later in life (Eccles \& Roeser, 2003, p. 130). Good performance in high school increases the likelihood of a successful transition to the university level. Academic performance 
in high school is shaped by at least two complementary groups of factors; some of them evolve from the internal climate of the school (Adams \& Berzonsky, 2003), and others issue from the private lives of students. Both categories of factors are important; however, in this study we focus on the second category of factors. More specifically, we turn our attention to the possible role of health-related behaviours of adolescents, such as sexual debut and substance use, on the results of the final examination in high school.

In order to properly understand the way in which the formal experience of schooling and its development and performance-oriented approach intertwine with sexual and health risk behaviour, we reviewed the main results of the most recent research regarding the life experience of young, middle-class heterosexuals from NorthAmerica and Europe.

When analyzing the relations with the opposite sex, it has been noticed, that tenth graders (15-16-year-old teenagers) interact more often with their romantic partners than with their parents, siblings or friends (Laursen \& Williams, 1997, apud Bouchey \& Furman, 2003, p. 314). Furthermore, partners involved in long-term romantic relationships are likely to become havens and sources of safety for each other (Fraley \& Davis, 1997). Naturally, adolescents' romantic experiences do not automatically involve sexual relations, but very frequently they precede the beginning of their sexual lives (Mureşan \& Oaneş/Faludi, 2007).

Since the second half of the $20^{\text {th }}$ century, age at which young people have their first intercourse has decreased significantly. Entering adult sexuality has progressively become more and more autonomous, with regard to both marriage and the establishment of steady relationships. The first sexual experience marks, together with other life events (e.g. finishing studies, finding a job, leaving home), the passage towards adult life (Ongaro, 2004; Rada, 2013) in the way that sexual behaviour at young age impacts the reproductive potential in later life. This is a reason for including sexual debut in the health-related behaviour in adolescence.

The literature shows that the adolescents' attitudes toward school might have an impact on their sexual conduct. When school performance and education is concerned, teenagers with higher educational aspirations and better school performance tend to postpone their first sexual encounter (Miller \& Sneesby, 1988) and have a less regular sexual life (Bingham \& Crockett, 1996). The time dedicated to school activities is associated negatively with early sexual involvement, especially with girls (Whitbeck et al., 1999). Poorer school performance and pessimistic expectations towards future school achievements correlate with an early start of sexual life and other risk factors regarding sexually transmitted diseases (STDs) (Harvey \& Spigner, 1995). In the context of Romania, Rada $(2013,2014)$ showed that risky sexual behaviours (early age of first sex, unsafe sex with occasional partners, precarious sexual and reproductive health education) are especially common among the young population at risk (younger youth, those residing in rural areas and with a low level of education). 
Bingham and Crockett (1996) have discovered that adolescents who had sexual relations at the beginning, in the middle and at the end of their adolescence have had different life trajectories. Teenagers with early sexual experiences showed a longitudinal pattern of poor adjustment in terms of several areas, including school performance, family relationships and behaviour. It seems that the sudden end of intimate relations is associated with negative effects, such as diminished self-respect and poor school performance.

The precocity of romantic and sexual relations has turned out to be negatively associated with risky health behaviours as well. Thus, the adolescents who have a romantic or sexual relationship at an early age are more likely to turn to alcohol and drugs and have poorer school performance (Aro \& Taipale, 1987). Nevertheless, the cause and effect relation between early romantic involvement and such problematic behaviour has not been very clearly defined and established, as there are two types of relationships, such that induce risky behaviours, and the behaviour that triggers early romantic involvement (Pawlby et al., 1997).

The increasing number of adolescents who are heavy consumers of different substances (tobacco, alcohol and drugs) and the decrease in the age at which they turn to these substances are reasons to worry, as they present powerful risk indicators for health and social difficulties during their teenage and adult life. The consumption and abuse of substances in childhood and adolescence may compromise the proper development of some important social and cognitive skills, which are essential in the process of growing, maturation and preparation for the tasks of adolescent and young adult life (Windle \& Windle, 2003, pp. 451, 465).

To sum up, learning and accomplishing school tasks during high school years is an essential condition for teenagers' further educational career and enrolling university studies, which is perceived, by many young people, as an important event of one's passing towards adult life and the improvement of quality of life on the long-term (Montgomery \& Côté, 2003, p. 149). In Romania, university entrance examination must be preceded by the Baccalaureate. In this respect, $12^{\text {th }}$ graders are required to invest additional efforts in their last year of high school, in order to take this examination. Our aim is to investigate relationships between successful high school graduation, and the health risk behaviours of sexual debut and substance consumption among Romanian adolescents in the final year of high school.

\section{Methods}

Taking into consideration the arguments presented in the introduction, we intend to investigate the relationship between the debut of sexual activity and health risk behaviours, emerging during adolescence, and performance at Baccalaureate. We have to mention that this aspect has not been explored by internal or external studies on school performance.

The Romanian Baccalaureate is a compulsory nationwide examination held when one graduates from the secondary education cycle (called Liceu, commonly referred 
to as high school), which in this paper is defined as high school studies. High school studies span four years in Romania and students must take this final examination at the age of 18 or 19 , and after 12 years of studies in total. The Baccalaureate is a single degree qualification test based on a 10-point scale academic grading system (graded out of 10 with a pass mark of 6), and it is a prerequisite for enrolling institutions of higher education. Baccalaureate examination results are a prerequisite for entering university enrolment examinations.

We investigated if the students who participated in our study were sexually active (1) or not (0) at the moment the research was carried out. In the statistical analysis the value 1 (one) refers to the presence of a condition, while 0 (zero) stands for its absence. Those participants who were sexually active (1) were asked for information regarding the age they had started their sexual life (17-18 years of age - value 1;1921 years of age - value 0 ), their relationship with the first sexual partner, and the number of partners they had had (one partner - value 0 ; two or more partners value 1). The type of relationship with the partner at the time of first sexual act was recorded as a dichotomized value: steady relationship (0) and occasional relationship (1). The health risk behaviours included in this investigation concerned the students' experience with alcohol (whether they had ever been drunk), consumption of illegal substances (including spices/ethnobotanicals), and smoking habits. They were assessed as answers to the following questions: "Have you ever been in an advanced state of being drunk?" - values 1 (yes) and 0 (no); "Have you ever tried or used some illegal drug (including ethnobotanicals)?" - values 1 (yes) and 0 (no); and “Do you smoke?" - Yes, at present (1); Yes, in the past, and No (0).

\section{Data Source and Sample Characteristics}

This study uses data from a self-administered questionnaire on School Success Profile. The present approach can be linked to a larger perspective, the study of life course, which is why the profile of the questionnaire corresponds to a follow-up study design. The questionnaire was applied in high schools in Romania, in May 2012. For the initial field study we selected a random sample of high school students from the $12^{\text {th }}$ grade, although we did not use the probability sampling technique. Later, once the Baccalaureate examination ended, we used a follow-up type of investigation, in order to find out information on the subjects' performance and results.

From the initial sample, we were able to find out information regarding their success on the Baccalaureate examination for 401 subjects. Out of these, 248 (61.8\%) were girls and 153 boys. The average age of the sample was 18 . As far as residence is concerned, $45 \%$ of the subjects came from rural areas.

\section{Data Analysis}

The design of this research has allowed us to establish the correspondence between the information obtained on social and demographic features, sexual behaviour and health risk behaviour of teenagers (obtained in the first phase of the investigation), 
and the information obtained on their results on the Baccalaureate (obtained during the second phase of the study). The data were analysed with the SPSS 19 program. In accordance with the study objectives, we used the techniques of inferential and multivariate analysis, binary logistic regression. Both in the inferential and regression analyses, we have taken into account the same two dependent variables, namely: taking the Baccalaureate examination and the results obtained on the Baccalaureate examination. Taking the Baccalaureate examination is one dependent variable with the potential values yes ( 0 ) and no (1). The value 1 (one) refers to the presence of the condition, while 0 (zero) stands for its absence. The results of the Baccalaureate examination represent another dependent variable with a theoretical value range from 1 to 10, according to the academic grading system in Romania. In this sense, codification of the dependent variable is necessary, and it needs to be carried out in such a way as to obtain two categories of responses, codified 0 or 1 (1 meaning, in this case, less than 7.87 grade points at the examination, based on the sample mean).

We used inferential analysis to investigate the relationship between the studied teenagers' sexual behaviour and successful accomplishment of high school studies. Thus, by comparing their performance expressed by means of the academic grading system (on a 10-point scale) and establishing whether they had to re-take any of the examinations in the last semester of the $12^{\text {th }}$ grade (1) or not (0), we checked whether the average age of the beginning of sexual life induced differences on the participants' Baccalaureate exam performance. In addition, with the help of association, we tested for significant relations between sexual status (sexually active/inactive), the type of relation with the first sexual partner, and the number of partners they had had on the one hand, and their performance at the Baccalaureate exam, on the other hand.

The aim of the multivariate analysis was to identify which features of sexual and health risk behaviours are related to failure on the Baccalaureate, and poor results on this important examination. In order to do this, we designed and created two distinct models of logistic regression, one for each dependent variable.

Binary logistic regression is a model that uses one dichotomic dependent variable to examine the existence and intensity of the relation between the interest variable and one or more explanatory or independent variables. The logistic regression model quantifies the effects of the explanatory variables, in terms of the odds ratio. When working with independent category variables, as is the case in this study, we will report on each of them in terms of a reference category, codified by 1 . Thus, an odds ratio higher than 1 will indicate a positive association, and a lower than 1 odds ratio will express a negative association (Greene, 2000; Harrell, 2001).

In the case of the multivariate analysis, we were also interested in the students' performance and his/her failure in passing one of the subject matters during the last semester of studies, as we wished to investigate the explanatory power of regressive models. This variable was added to the list of independent variables, being dichotomized. We excluded from the regressive analysis the independent variables 
related to sexual behaviour, as they proved to be irrelevant related to Baccalaureate performance. As control variables we used sex, age, religious practice, and self-rated health.

\section{Results}

Following the descriptive analysis of the data, we concluded that there was a significant link between failure on the Baccalaureate and the conditions in which the first sexual act occurred.

Results from Table 1 show that, among the high school students who were sexually active, the first sexual encounter had occurred a year earlier in those who failed the Baccalaureate, as compared to the students who passed the examination. The association seems to have been even stronger when dealing with the type of relationship at the time of the first sexual act or the number of sexual partners. Thus, the students who first had sex in an occasional relationship and those with several partners failed the Baccalaureate or had poor results at a significantly higher percentage than those who reported a steady relationship at the time of the first sexual act (at least 3 months long) or who had had sex with only one partner up to the moment of the investigation.

Table 1

Relation between Indicators of Sexual Behaviour and Baccalaureate Results

\begin{tabular}{|c|c|c|c|c|c|c|}
\hline \multirow{2}{*}{ Study variables } & \multicolumn{3}{|c|}{ Failure on the Baccalaureate } & \multicolumn{3}{|c|}{ Poor results on the Baccalaureate } \\
\hline & $\begin{array}{c}\text { Yes } \\
(n, \%)\end{array}$ & $\begin{array}{c}\text { No } \\
(n, \%)\end{array}$ & $\begin{array}{c}\text { Sig. level } \\
p\end{array}$ & $\begin{array}{c}\text { Yes } \\
(n, \%)\end{array}$ & $\begin{array}{c}\text { No } \\
(n, \%)\end{array}$ & $\begin{array}{c}\text { Sig. level } \\
p\end{array}$ \\
\hline $\begin{array}{l}\text { Sexually active } \\
\text { Yes } \\
\text { No }\end{array}$ & $\begin{array}{l}53(27.6) \\
30(16.9)\end{array}$ & $\begin{array}{l}139(72.4) \\
148(83.1)\end{array}$ & $\chi^{2}=6.135^{* *}$ & $\begin{array}{l}75(53.6) \\
68(46.3)\end{array}$ & $\begin{array}{l}65(46.4) \\
79(53.7)\end{array}$ & $\chi^{2}=1.534$ (ns) \\
\hline \multirow{2}{*}{$\begin{array}{l}\text { Average age at the } \\
\text { time of the first } \\
\text { sexual act }\end{array}$} & 15.75 & 16.71 & \multirow{2}{*}{$t=3.266^{* * *}$} & 16.46 & 16.96 & \multirow{2}{*}{$\mathrm{t}=2.507^{* *}$} \\
\hline & Dif. averag & $\begin{array}{l}\text { alues }=0.96 \\
\text { rs }\end{array}$ & & $\begin{array}{r}\text { Dif. avera } \\
0.5\end{array}$ & $\begin{array}{l}\text { values = } \\
\text { ars }\end{array}$ & \\
\hline
\end{tabular}

Relationship with the partner at the time of the first sexual act Occasional Steady

Number of sexual partners

2 and above

1 partner

$\chi^{2}=10.697^{* * *}$ $\chi^{2}=17.179^{* * *}$

Note $^{* * *} \mathrm{p}<0.01 \quad{ }^{* *} 0.01 £ \mathrm{p}<0.05 \quad{ }^{*} 0.05 £ \mathrm{p}<0.1 \quad \mathrm{~ns}=$ not significant

The results of the multivariate analysis are illustrated in Table 2. When adjusted for sex, age, religious practice and health status, the significant results can be grouped into three categories. In their gradual importance regarding the impact on the results achieved on 
the Baccalaureate, we mention the socio-demographic variables, the factors related to the academic process and the explanations linked with the debut of sexual activity. The first category of factors includes the current place of residence and the socio-economic status of the family. It seems that the risk of failure at the final examination is more than twice as great among the students residing in rural areas, which are usually disadvantaged regions in Romania, compared with the students from urban areas.

Table 2

Logistic Regression Analysis on the Odds of Failure and Poor Baccalaureate Results

\begin{tabular}{|c|c|c|c|c|}
\hline \multirow[t]{2}{*}{ Study variables } & \multicolumn{2}{|c|}{$\begin{array}{l}\text { Odds of failure on the } \\
\text { Baccalaureate } \\
\qquad(\mathrm{N}=185)\end{array}$} & \multicolumn{2}{|c|}{$\begin{array}{l}\text { Odds of poor results on the } \\
\text { Baccalaureate } \\
\qquad(\mathrm{N}=135)\end{array}$} \\
\hline & $\operatorname{Exp}(B)$ & $p$ & $\operatorname{Exp}(B)$ & $p$ \\
\hline $\begin{array}{l}\text { Sex } \\
\text { Male } \\
\text { Female (ref.) }\end{array}$ & 2.907 & $* *$ & 1.501 & ns \\
\hline $\begin{array}{l}\text { Age } \\
17-18 \text { years old } \\
19-21 \text { years old (ref.) }\end{array}$ & 1.538 & ns & 0.645 & ns \\
\hline $\begin{array}{l}\text { Residence at present } \\
\text { Rural } \\
\text { Urban (ref.) }\end{array}$ & 2.347 & $* *$ & 1.508 & ns \\
\hline $\begin{array}{l}\text { Re-take exam in the last semeste } \\
\text { No (ref.) } \\
\text { Yes }\end{array}$ & 2.072 & * & 4.642 & $* *$ \\
\hline $\begin{array}{l}\text { Religious practice } \\
\text { Yes (ref.) } \\
\text { No }\end{array}$ & 1.360 & ns & 0.854 & ns \\
\hline $\begin{array}{l}\text { Self-rated health } \\
\text { Poor } \\
\text { Fair } \\
\text { Very good / good (ref.) }\end{array}$ & $\begin{array}{l}0.840 \\
1.408\end{array}$ & $\begin{array}{l}\text { ns } \\
\text { ns }\end{array}$ & $\begin{array}{l}1.658 \\
1.758\end{array}$ & $\begin{array}{l}\text { ns } \\
\text { ns }\end{array}$ \\
\hline $\begin{array}{l}\text { Relationship with the partner at } \\
\text { the time of the first sexual act } \\
\text { Occasional } \\
\text { Steady relationship (ref.) }\end{array}$ & 2.978 & $* *$ & 5.576 & $* * *$ \\
\hline $\begin{array}{l}\text { Low socio-economic status } \\
\text { No (ref.) } \\
\text { Yes }\end{array}$ & 2.834 & $* *$ & 1.179 & ns \\
\hline $\begin{array}{l}\text { Consumption of illegal } \\
\text { substances } \\
\text { No (ref.) } \\
\text { Yes }\end{array}$ & 1.530 & ns & 1.770 & ns \\
\hline $\begin{array}{l}\text { Smoking } \\
\text { Yes, at present (ref.) } \\
\text { Yes, in the past } \\
\text { No }\end{array}$ & $\begin{array}{l}0.437 \\
0.545\end{array}$ & $\begin{array}{l}\text { ns } \\
\text { ns }\end{array}$ & $\begin{array}{l}0.736 \\
0.729\end{array}$ & $\begin{array}{l}\text { ns } \\
\text { ns }\end{array}$ \\
\hline $\begin{array}{l}\text { Ever been drunk } \\
\text { No (ref.) } \\
\text { Yes }\end{array}$ & 0.371 & $* *$ & 0.826 & ns \\
\hline
\end{tabular}


The risk of failure is almost three times higher among the students of a low socioeconomic background in comparison with the students of a higher socio-economic status. As expected, the second category of explanatory variables is even more prevalent in the achievement on the Baccalaureate. So, students who had to re-take their examinations in the last semester of the $12^{\text {th }}$ grade had two times higher odds of failing the final examination compared to those who did not have this difficulty. Even those who had to re-take their examinations during the $12^{\text {th }}$ grade and passed the final examination had more than four times higher odds to obtain poor results on the Baccalaureate exam compared to those who were doing well during the academic year. However, a private aspect of the student's intimate life proved to play a leading role in the success on the Baccalaureate exam. It seems that the stability in students who are in steady relationships in their $12^{\text {th }}$ grade may help them do well on the Baccalaureate. Thus, the students who started their sexual life with an occasional partner, whom they hardly knew, were three times more likely to fail the examination and almost six times more likely to have poor results on it, as compared to the subjects who were in a steady relationship at the time of their first sexual encounter.

The coefficients of the logistic regression, together with the significance levels, indicate that the students from rural areas, and of a poor social and economic background or with re-take examinations in the last semester of the $12^{\text {th }}$ grade, have higher odds of failing the Baccalaureate exam or obtaining poor results on it. Nevertheless, the most important factor intervening in achieving success on the Baccalaureate is the type of sexual partnerships students are involved into. Starting the sexual life in the context of an occasional encounter does not only reduce their chance to pass the final exam, but also strongly increases the probability to obtain poor results, which can negatively affect their future university education. These results are significant with the data adjusted, controlled for sex, age, religious practice, and health status.

In the context of the multivariate analysis, health risk behaviours do not seem to have a significant effect on the students' performance on the examination, and this could be due to the fact that in the experimental, beginner consumers, the effects of these substances do not readily impact school performance.

\section{Discussion}

Our study revealed that if we aim at improving performance on the Baccalaureate examination, we should take into account the complexity of the contributing factors, which are related to the socio-economic background, to the academic achievements during high school, and to the aspects of the private life of the students. We will concentrate in our conclusions on the last category of factors, those related to the sexual behaviour of students in their adolescence.

In their study on adolescent sexuality, Luster and Small (1994) divide teenagers into three types: high risk adolescents (with several partners and who seldom or 
never use any contraceptive methods), low risk adolescents (with one partner only and who always use some contraceptive methods) and abstinent or sexually inactive adolescents. The two authors claim that engaging in risky sexual activities during this period (from adolescence until young adulthood), can have major consequences upon school performance and success.

Similarly, this study has shown that among the sexually active Romanian teenagers there are at least two different subgroups, in which the risk of failing the Baccalaureate related to the subjects' sexual life is concerned. One of the subgroups presents low risks of failing the final examination at the end of high school, and is made up of the students who start their sexual life later, with a steady partner with whom they remain together during high school years. The other subgroup is at a greater risk of failing at the Baccalaureate examination, and it includes those students who start their sexual lives early, with occasional partners and who tend to switch partners and have short and transient relationships (Moore \& Rosenthal, 1993).

This categorization could be useful in the setting up of prevention programmes for risky health and sexual behaviours, which, if unsolved, could hinder students' access to higher education. Although enrolling university is not the only or the most important way to reach adulthood, we have to admit that in Romania there are quite a few young people who still consider that the experience of being a university student is an essential step towards maturation. For the young people who choose to go to university for this reason, the very first obstacle is the Baccalaureate (Montgomery \& Côté, 2003, pp. 151, 158). Naturally, this transition from the status of a high school student to the one of a university student implies taking this examination. For this reason, this investigation, targeting the role played by risky sexual and health behaviours in school performance and Baccalaureate results, has turned out to be a useful and timely one.

The results of this study could open new perspectives of research by attempting to answer questions such as: What role do sexual encounters play in the professional carrier of adolescents? Do sexual experiences have a role that goes beyond the role played by important and influential peers/people? Do sexual experiences offer something unique to the process of socialization? We hope that the answers that we provided in this study will stimulate future theoretical debates and the publication of other empirical studies in the fascinating field of adolescent sexuality.

\section{Conclusions}

But most probably, conclusions and lessons that we could learn and use for future prevention and intervention programmes are even more important than these answers. We plead for the education of children and adolescents which would cease to be a strictly formal activity based on grades, performance and competition, but it would rather be based on a curriculum that has a strong sense for health education. This should consider the personality as a whole, helping adolescents to become healthy and well functioning adults. Programmes of health education should include aspects 
regarding reproductive health and family planning, and their focus should move from transmitting information on contraception, preventing pregnancy and preventing sexually transmitted diseases to broader and longer-term approaches, which rely on the dynamics of relationships (Finer et al., 1999), the dynamics of sexual networks and the transmission patterns within the networks (Aral, 1999). Thus, the basic unit of future educational programmes should not be the individual, but rather the couple and one of the topics in this shift should be the exclusivity within the couple, as a factor of stability and support in school performance, and as a protective factor in the sexual and health behaviour of adolescents.

\section{Declaration of Authors}

Csaba László Dégi and Cristina Faludi have contributed to the collection of data, to their introduction into the SPSS database; they have carried out the statistical analyses and have written and revised the text of this study.

\section{Acknowledgments}

This work was supported by a grant of the Romanian National Authority for Scientific Research, CNCS - UEFISCDI, project number PN-II-ID-PCE-2011-3-0543.

\section{References}

Aral, S.O. (1999). Sexual network patterns as determinants of STD rates: Paradigm shift in the behavioural epidemiology of STDs made visible. Sexually Transmitted Diseases, 26, 262-264. http://dx.doi.org/10.1097/00007435-199905000-00004

Aro, H., \& Taipale, V. (1987). The impact of timing of puberty on psychosomatic symptoms among fourteen- to sixteen-year-old Finnish girls. Child Development, 58, 261-268. http:// dx.doi.org/10.2307/1130306

Bingham, C.R., \& Crockett, L.J. (1996). Longitudinal adjustment patterns of boys and girls experiencing early, middle, and late sexual intercourse. Developmental Psychology, 32, 647658. http://dx.doi.org/10.1037/0012-1649.32.4.647

Bouchey, H.A., \& Furman, W. (2003). Dating and Romantic Experiences in Adolescence. In G.R. Adams \& M.D. Berzonsky (Eds.), Blackwell Handbook of Adolescence (pp. 313-329). Oxford: Blackwell Publishing Ltd.

Eccles, J.S., \& Roeser, R.W. (2003). Schools as Developmental Contexts. In G.R. Adams \& M.D. Berzonsky (Eds.), Blackwell Handbook of Adolescence (pp. 129-148). Oxford: Blackwell Publishing Ltd. 
Finer, L.B., Darroch, J.E., \& Singh, S. (1999). Sexual partnership patterns as a behavioural risk factor for sexually transmitted diseases. Family Planning Perspectives, 31, 228-236. http://dx.doi.org/10.2307/2991570

Fraley, R.C., \& Davis, K.E. (1997). Attachment formation and transfer in young adolescents' close friendships and romantic relationships. Personal Relationships, 4, 131-144. http:// dx.doi.org/10.1111/j.1475-6811.1997.tb00135.x

Greene, W.H. (2002). Econometric analysis. Prentice Hall, Upper Saddle River.

Harrell, F.E. (2001). Regression Modeling Strategies. With Applications to Linear Models, Logistic Regression, and Survival Analysis. New York: Springer-Verlag. http://dx.doi. org/10.1007/978-1-4757-3462-1

Harvey, S.M., \& Spigner, C. (1995). Factors associated with sexual behaviour among adolescents: A multivariate analysis. Adolescence, 30, 253-264.

Luster, T., \& Small, S.A. (1994). Factors associated with sexual risk-taking behaviours among adolescents. Journal of Marriage and the Family, 56, 622-632. http://dx.doi. org/10.2307/352873

Miller, B.C., \& Sneesby, K. (1988). Educational correlates of adolescents' sexual attitudes and behaviour. Journal of Youth and Adolescence, 17, 521-530. http://dx.doi.org/10.1007/ BF01537829

Montgomery, M.J., \& Côté, J.E. (2003). College as a Transition to Adulthood. In G.R. Adams \& M.D. Berzonsky (Eds.), Blackwell Handbook of Adolescence (pp. 149-172). Oxford: Blackwell Publishing Ltd.

Moore, S., \& Rosenthal, D. (1993). Sexuality in adolescence. New York: Routledge.

Mureşan, C., \& Oaneş/Faludi, C. (2007). Romania. In F.C. Billari, M. Caltabiano, \& G. Dalla Zuanna (Eds.), Sexual and affective behaviour of students. An international research (pp. 177-199). Padova: Cleup Editrice.

Ongaro, F. (2004). Entry into adult sexuality: an international outline. In G. Dalla Zuanna, \& C. Crisafulli (Eds.), Sexual Behaviour of Italian Students (pp. 3-18). University of Messina: Department of Statistics.

Pawlby, S.J., Mills, A., \& Quinton, D. (1997). Vulnerable adolescent girls: Opposite-sex relationships. Journal of Child Psychology and Psychiatry, 38, 909-920. http://dx.doi. org/10.1111/j.1469-7610.1997.tb01610.x

Rada, C. (2013). Valori identitare ale familiei româneşti contemporane în contextul globalizării. O abordare antropologică. Bucureşti: Editura Muzeului Naţional al Literaturii Române.

Rada, C. (2014). Sexual behaviour and sexual and reproductive health education: a cross-sectional study in Romania. Reproductive Health, 11:48, 1-16/online/. Retrieved on 24th June 2014 from http://www.reproductive-health-journal.com/content/11/1/48. doi:10.1186/1742-4755-11-48. http://dx.doi.org/10.1186/1742-4755-11-48

Whitbeck, L.B., Yoder, K.A., Hoyt, D.R., \& Conger, R.D. (1999). Early adolescent sexual activity: a developmental study. Journal of Marriage and the Family, 61, 934-946. http:// dx.doi.org/10.2307/354014

Windle, M., \& Windle, R.C. (2003). Alcohol and Other Substance Use and Abuse. In G.R. Adams \& M.D. Berzonsky (Eds.), Blackwell Handbook of Adolescence (pp. 450-469). Oxford: Blackwell Publishing Ltd. 


\section{Csaba Laszlo Degi}

Faculty of Sociology and Social Work, Babes-Bolyai University Strada Mihail Kogălniceanu 1, Cluj-Napoca 400084, Romania csabadegi@gmail.com

\section{Cristina Faludi}

Faculty of Sociology and Social Work, Babes-Bolyai University Strada Mihail Kogălniceanu 1, Cluj-Napoca 400084, Romania cristina.faludi@gmail.com 


\section{Utjecaj prvog spolnog odnosa i rizičnog zoravstvenog ponašanja na uspjeh rumunjskih adolescenata na maturi}

\section{Sažetak}

Međuodnos spolnog i rizičnog zdravstvenog ponašanja i školskog uspjeha rijetko se istražuje u zemljama središnje $i$ istočne Europe. Ovim se projektom istražuje njihov učinak na rezultate obveznog maturalnog ispita (engl. Baccalaureate) $u$ Rumunjskoj. U ovoj popratnoj analizi obradeni su odgovori 401 maturanta. Izmjerili smo školski uspjeh s pomoću indikatora napretka i uspjeha u standardiziranim testovima. Upitnikom za samostalno popunjavanje o profilu školskoga uspjeha obuhvaćena su pitanja o rizičnom zdravstvenom ponašanju adolescenata (pušenje, neumjereno opijanje i ilegalna zloupotreba droga) i njihovim prvim spolnim odnosima. $U$ analizi su upotrijebljene metode deskriptivne statistike i logističke regresije. Rezultati su pokazali da su učenici iz ruralnih krajeva, zahvaćenih oskudicom, koji su u posljednjem semestru ocijenjeni negativnim ocjenama i koji su bili u nestabilnim vezama u trenutku prvog spolnog odnosa imali velike predispozicije da padnu razred i dobiju niže prosječne ocjene na završnom ispitu, s korekcijom za dob, spol, vjeru i zdravstveno stanje. U okviru zdravstvenog odgoja nastavnici ne bi trebali zanemarivati edukaciju o reproduktivnom zdravlju, a znanje stečeno tijekom obrazovanja trebalo bi adolescente služiti tijekom cijelog njihova života.

Ključne riječi: mladi odrasli ljudi; prvi spolni odnos; školski uspjeh.

\section{Uvod}

Srednja je škola glavna formalna organizacija koja ima utjecaj na pubertet kao fazu životnoga ciklusa okarakteriziranu posebnim vrijednostima, normama i rutinama koje imaju veliku ulogu u intelektualnom, društveno-emocionalnom razvoju adolescenata i razvoju ponašanja u njihovu kasnijem životu (Eccles i Roeser, 2003, str. 130). Dobar uspjeh u srednjoj školi povećava vjerojatnost uspješnog prijelaza na sveučilišnu razinu. Akademski uspjeh u srednjoj školi rezultat je barem dviju komplementarnih skupina čimbenika; neke od njih razvijaju se iz školskog ozračja (Adams i Berzonsky, 2003), a drugi potječu iz privatnih života učenika. Obje su kategorije čimbenika važne, no 
u ovome se istraživanju usredotočujemo na drugu kategoriju, odnosno bavimo se mogućom ulogom rizičnog zdravstvenog ponašanja adolescenata, poput prvog spolnog općenja i zloupotrebe opojnih droga, u postizanju određenih rezultata na maturi.

Da bismo utvrdili kako se formalno školsko iskustvo i njegov razvoj i pristup usmjeren na izvedbu isprepleću sa spolnim i rizičnim zdravstvenim ponašanjem, pregledali smo glavne rezultate najrecentnijih istraživanja životnoga iskustva mladih heteroseksualaca srednjega staleža iz Sjeverne Amerike i Europe.

Pri analizi odnosa sa suprotnim spolom primijećeno je da učenici desetih razreda (petnaestogodišnjaci i šesnaestogodišnjaci) češće komuniciraju sa svojim partnerima nego sa svojim roditeljima, braćom, sestrama i prijateljima (Laursen i Williams, 1997, u Bouchey i Furman, 2003, str. 314). Osim toga, mladi ljudi koji su u stalnim dugotrajnim vezama jedno drugome lako postaju utočište i izvor sigurnosti (Fraley i Davis, 1997). Jasno, romantična iskustva adolescenata ne uključuju automatski spolne odnose, ali vrlo često predstoje početku njihova spolnoga života (Mureşan i Oaneş/Faludi, 2007).

Od sredine dvadesetoga stoljeća mladi ljudi svoj prvi spolni odnos imaju u sve ranijoj dobi. Ulazak u razdoblje zrele spolnosti postalo je sve autonomnije u odnosu na brak i zasnivanje stalnih odnosa. Prvo spolno iskustvo, zajedno s drugim životnim događajima (npr. završetak studija, pronalaženje posla, napuštanje roditeljskoga doma), označava ulazak u život odraslih (Ongaro, 2004; Rada, 2013) jer spolno ponašanje u ranoj dobi utječe na reproduktivni potencijal u kasnijem životu. Zbog toga je prvi spolni odnos uvršten u čimbenike zdravstveno rizičnoga ponašanja u pubertetu.

U literaturi nalazimo da stavovi adolescenata prema školi mogu utjecati na njihovo spolno ponašanje. Kad su u pitanju školski uspjeh i obrazovanje, tinejdžeri s višim obrazovnim ambicijama i boljim školskim uspjehom odgađaju svoj prvi spolni odnos (Miller i Sneesby, 1988) i imaju manje redovit spolni život (Bingham i Crockett, 1996). Vrijeme posvećeno školskim aktivnostima negativno je povezano s ranim spolnim odnosnima, osobito u djevojčica (Whitbeck i dr., 1999). Slabiji školski uspjeh i pesimistična predviđanja o budućem školskom uspjehu u korelaciji su s ranim početkom spolnoga života i ostalim čimbenicima rizika povezanih sa spolno prenosivim bolestima (Harvey i Spigner, 1995). U rumunjskom kontekstu, Rada (2013, 2014) pokazuje da je rizično spolno ponašanje (prvi spolni odnos u ranoj dobi, spolni odnosi bez zaštite i povremeni partneri, loša zdravstvena i spolna edukacija) osobito često među rizičnom populacijom mladih ljudi (mladi ljudi iz ruralnih krajeva, lošijega obrazovanja).

Bingham i Crockett (1996) ustanovili su da su adolescenti koji su imali spolne odnose na početku, usred i na kraju puberteta imali različite životne putanje. U tinejdžera s ranim spolnim iskustvima zabilježen je longitudinalni uzorak slabe prilagodbe u raznim sferama njihovih života, između ostaloga u školskome uspjehu, obiteljskim odnosima i njihovu ponašanju. Čini se da je nagli završetak intimnih odnosa povezan s negativnim učincima, kao što su to umanjivanje samopoštovanja i loš uspjeh u školi. 
Pokazalo se da se prerana zrelost romantičnih i spolnih odnosa također negativno asocira s rizičnim zdravstvenim ponašanjem. Stoga su adolescenti koji se rano upuštaju u romantične ili spolne odnose skloniji alkoholu i drogama te postižu slabiji uspjeh u školi (Aro i Taipale, 1987). No odnos uzroka i posljedice između ranog romantičnog odnosa i spomenutog problematičnog ponašanja dosad nije dobro definiran i utemeljen. Razlog nepostojanja jasne definicije jest to što se može raditi o odnosima koji pospješuju rizično ponašanje i o ponašanju koje je okidač ranim romantičnim odnosima (Pawlby i dr., 1997).

Porast u broju adolescenata koji konzumiraju različite štetne tvari (duhan, alkohol, droge) i činjenica da ih počinju konzumirati u sve ranijoj dobi razlozi su za brigu jer predstavljaju snažne indikatore rizika zdravstvenih i društvenih poteškoća s kojima se pojedinci susreću u tinejdžerskom i odraslom životu. Konzumacija i zloupotreba štetnih tvari u djetinjstvu i pubertetu mogu kompromitirati razvoj nekih važnih društvenih i kognitivnih vještina koje su ključne u procesu rasta, sazrijevanja $i$ pripreme za životne zadatke adolescenta i mlade odrasle osobe (Windle i Windle, 2003, str. 451, 465).

Sve u svemu, učenje i uspjeh u školskim zadatcima tijekom srednje škole predstavljaju temeljni uvjet za buduće obrazovanje učenika i upis na fakultet, što mnogi mladi ljudi smatraju važnim događajem svog prijelaza u svijet odraslih i dugoročni napredak $u$ kvaliteti života (Montgomery i Côté, 2003, str. 149). Prije nego pristupe polaganju prijemnoga ispita za upis na fakultet, mladi u Rumunjskoj moraju položiti državnu maturu. Tako se od učenika dvanaestih razreda traži da ulože dodatan napor tijekom posljednjih godina srednje škole kako bi položili taj ispit. Naš je cilj bio istražiti povezanost između uspješnog polaganja mature i rizičnog zdravstvenog ponašanja $u$ smislu prvog spolnog odnosa i zloupotrebe štetnih tvari u rumunjskih adolescenata tijekom njihovih posljednjih godina srednjoškolskoga obrazovanja.

\section{Metode}

Uzimajući u obzir argumente koje smo iznijeli u uvodu, namjera nam je bila istražiti odnos između vremena početka spolnih odnosa i rizičnog zdravstvenog ponašanja koji se pojavljuju tijekom puberteta i uspjeha na maturi. Napominjemo da taj aspekt nije istražen u internim i eksternim studijama školskoga uspjeha.

Rumunjska matura obvezan je nacionalni ispit koji se polaže na kraju srednjoškolskoga ciklusa (licej, često nazvan srednja škola). Srednja škola u Rumunjskoj traje četiri godine, a učenici maturu polažu u dobi od 18 ili 19 godina, nakon 12 godina školovanja. Matura je kvalifikacijski ispit na temelju kojega učenici dobivaju diplomu. Ocjene se temelje na sustavu ocjenjivanja u rasponu od 1 do 10 (najviša ocjena je 10, a prolazna je ocjena 6) te predstavlja preduvjet za upis na visokoškolske institucije. Rezultati mature uvjet su za prijavu na prijemne ispite za fakultete.

Istražili smo jesu li učenici koji su sudjelovali u našemu istraživanju bili spolno aktivni (1), ili nisu (0) u trenutku provođenja istraživanja. U statističkoj se analizi 
vrijednost 1 (jedan) odnosi na postojanje uvjeta, a 0 (nula) na njegovu odsutnost. Ispitanici koji su se u trenutku provođenja istraživanja izjasnili da su spolno aktivni (1) upitani su o dobi kad su započeli svoj spolni život (17-18 godina - vrijednost 1; 19-21 godina - vrijednost 0 ), o odnosu sa svojim spolnim partnerom i o broju partnera koje su dotad imali (jedan partner - vrijednost 0 , dva ili više partnera vrijednost 1). Tip odnosa s partnerom $u$ trenutku prvog spolnog odnosa zabilježen je kao dihotomna varijabla: stalan odnos (0) i povremen odnos (1). Zdravstveno rizično ponašanje obuhvaćeno ovom studijom odnosilo se na iskustvo učenika s alkoholom (jesu li se ikad napili), zloupotrebom ilegalnih supstanci (uključujući začine/etnobotaničke biljke) i pušačkim navikama. Spomenuto je ponašanje ocijenjeno s pomoću odgovora na sljedeća pitanja: „Jeste li ikada bili u uznapredovalom stadiju pijanstva?“ - vrijednosti 1 (da) i 0 (ne); „Jeste li ikada probali ili konzumirali neku ilegalnu drogu (uključujući začine/etnobotaničke biljke)?" - vrijednosti 1 (da) i 0 (ne); i „Pušite li? “ - Da, trenutno (1); Da, u prošlosti, i Ne (0).

\section{Izvor podataka i karakteristike uzorka}

Upotrijebljen je upitnik za samostalno popunjavanje o profilu školskoga uspjeha. Taj je pristup povezan sa širom perspektivom, istraživanjem životnoga vijeka. Stoga taj profil upitnika odgovara nacrtu popratnog istraživanja. Upitnik je proveden u srednjim školama u Rumunjskoj u svibnju 2012. Za početno terensko istraživanje odabrali smo slučajan uzorak srednjoškolaca dvanaestoga razreda, iako se nismo koristili tehnikama slučajnog uzorkovanja. Nakon što je završio maturalni ispit, upotrijebili smo popratni oblik istraživanja kako bismo prikupili informacije o uspjehu i rezultatima ispitanika.

Iz početnog smo uzorka dobili informaciju o učeničkom uspjehu na maturi za 401 ispitanika, od čega 248 (61,8\%) djevojaka i 153 dječaka. Prosječna dob ispitanika bila je 18 . Što se tiče mjesta stanovanja, $45 \%$ ispitanika bilo je iz ruralnih krajeva.

\section{Analiza}

Dizajn istraživanja omogućio nam je da utvrdimo podudarnost između informacija o društvenim i demografskim karakteristikama, spolnom ponašanju i rizičnom zdravstvenom ponašanju tinejdžera (prikupljeno u prvoj fazi istraživanja) i informacija prikupljenih o njihovim rezultatima mature (prikupljeno tijekom druge faze istraživanja). Podatci su analizirani SPSS 10 programom. U skladu s ciljevima istraživanja upotrijebili smo tehnike inferencijske i multivarijatne analize, binarne logističke regresije. U inferencijskoj i regresijskoj analizi uzeli smo u obzir iste dvije nezavisne varijable: pristupanje ispitu mature i rezultate postignute na maturi. Pristupanje ispitu mature jedna je zavisna varijabla s potencijalnim vrijednostima da (0) i ne (1). Vrijednost 1 (jedan) odnosi se na prisutnost uvjeta, a 0 (nula) se odnosi na nepostojanje uvjeta. Rezultati postignuti na maturi predstavljaju još jednu zavisnu varijablu s teorijskim vrijednostima u rasponu od 1 do 10 , s obzirom na 
akademski sustav ocjenjivanja u Rumunjskoj. U tom je smislu neophodna kodifikacija zavisne varijable pa je treba provesti na način da se dobiju dvije kategorije odgovora kodificirane s 0 ili 1 ( 1 se u ovome slučaju odnosi na prosjek ocjena manji od 7,87, izračunat na temelju prosječne vrijednosti uzorka).

Inferencijalna analiza upotrijebljena je kako bi se istražio međuodnos spolnog ponašanja tinejdžera i uspješnoga završetka srednje škole. Tako smo, usporedivši njihov uspjeh izražen akademskim sustavom ocjenjivanja (na skali od 10 stupnjeva) i utvrdivši jesu li trebali ponovno polagati neki ispit u posljednjem semestru dvanaestoga razreda (1) ili nisu (0), istražili je li prosječna dob početka njihova spolnog života utjecala na razlike u njihovu uspjehu na maturi. Osim toga analizom podudarnosti testirali smo značajnost odnosa između spolnoga statusa (spolno aktivan / neaktivan), tipa odnosa s prvim spolnim partnerom i broja partnera koje su imali s jedne strane i njihova uspjeha na maturi s druge.

Cilj je multivarijatne analize bio utvrditi koji su čimbenici spolnog i rizičnog zdravstvenog ponašanja povezani s padom i lošim uspjehom na maturi. S tim ciljem osmislili smo i izradili dva različita modela logističke regresije, po jedan za svaku zavisnu varijablu.

Binarna logistička regresija model je koji se služi jednom dihotomnom zavisnom varijablom kako bi istražio postojanje i intenzitet odnosa između proučavane varijable i jedne ili više ekplanatornih ili nezavisnih varijabli s obzirom na odnos vjerojatnosti. $U$ radu s nezavisnim kategorijskim varijablama, kao što je to slučaj u ovome istraživanju, zasebno ćemo izvijestiti o svakoj nezavisnoj varijabli kao referentnoj kategoriji kodificiranoj s 1. Pri tome vjerojatnost viša od 1 označava pozitivan odnos, a niža od 1 označava negativnu asocijaciju (Greene, 2000; Harrell, 2001).

Pri izradi multivarijatne analize također smo bili zainteresirani za uspjeh učenika u polaganju jednog od školskih predmeta u posljednjem semestru srednje škole te smo željeli istražiti eksplanatornu moć regresijskih modela. Ta je varijabla dihotomizirana i dodana na popis nezavisnih varijabli. Iz regresijske smo analize isključili nezavisne varijable povezane sa spolnim ponašanjem jer se pokazalo da nisu utjecale na uspjeh na maturi. Kao kontrolne varijable upotrijebili smo spol, dob, vjeru i samoprocjenu osobnoga zdravstvenog stanja.

\section{Rezultati}

S pomoću deskriptivne analize utvrdili smo značajnu povezanost između neuspjeha na maturi i uvjeta u kojima je došlo do prvog spolnog odnosa.

Rezultati prikazani u tablici 1 pokazuju da su spolno aktivni učenici koji su pali maturu imali prvi spolni odnos godinu dana ranije od onih koji su taj ispit položili. Povezanost se pokazala još jačom kad se ispitao tip veze $u$ kojoj su ispitanici bili $u$ vrijeme prvog spolnog odnosa i broj spolnih partnera. Tako je značajno viši broj učenika koji su bili u usputnoj vezi u vrijeme prvog spolnog odnosa i onih koji su imali nekoliko partnera palo maturu, ili je na tom ispitu postigao slab uspjeh, za razliku 
od onih koji su bili u stalnoj vezi (barem tri mjeseca dugoj) u vrijeme prvog spolnog odnosa ili koji su spolno općili sa samo jednim partnerom do trenutka u kojem je provođeno istraživanje.

\section{Tablica 1.}

Rezultati multivarijatne analize prikazani su u tablici 2. Značajni rezultati s korekcijom za dob, spol, vjeru i zdravstveno stanje mogu se svrstati u tri kategorije. Socio-demografske varijable, čimbenici koji se odnose na akademski proces i pojašnjenja povezana s prvim spolnim odnosom značajno su utjecali na rezultate mature. Prva kategorija čimbenika odnosi se na boravište i socio-demografski status obitelji. Čini se da je rizik od pada na maturi više nego dvostruko veći u učenika iz često siromašnih ruralnih krajeva Rumunjske, u odnosu na učenike iz urbanih sredina.

Tablica 2.

Rizik od pada na maturi gotovo je tri puta veći među učenicima niskog socioekonomskog statusa u odnosu na učenike s višim socio-ekonomskim statusom. Kao što je očekivano, druga kategorija eksplanatornih varijabli još je češća u opisu rezultata mature. Vjerojatnost pada na maturi bila je dvostruko viša u učenika koji su morali ponovno polagati ispite u posljednjem semestru dvanaestoga razreda $u$ odnosnu na učenike koji nisu imali takvih problema. Vjerojatnost za postizanjem slabih rezultata na maturi bila je više nego četiri puta veća u učenika koji su morali ponovno polagati ispite $u$ dvanaestome razredu te su položili završni ispit u odnosu na one koji su imali dobar uspjeh tijekom akademske godine. No značajke privatnoga života učenika imale su vodeći utjecaj na uspjeh na maturi. Čini se da stabilnost stalne veze u dvanaestome razredu učenicima može pomoći u postizanju dobrog uspjeha na maturi. Tako je vjerojatnost pada na maturi bila trostruko veća, a vjerojatnost postizanja slabih rezultata gotovo šesterostruko veća u ispitanika koji su svoj spolni život započeli s usputnim partnerom u odnosu na ispitanike koji su bili u stalnoj vezi $\mathrm{u}$ vrijeme prvog spolnog odnosa.

Koeficijenti logističke regresije i stupnjevi značajnosti pokazuju da je vjerojatnost pada na maturi ili postizanja loših rezultata na tom ispitu bila viša u učenika iz ruralnih sredina, koji su bili lošijeg socio-ekonomskog statusa te koji su morali ponovno polagati ispite u posljednjem semestru dvanaestoga razreda. No, najvažniji čimbenik koji utječe na postizanje uspjeha na maturi jest tip spolnoga odnosa. Početak spolnoga života u kontekstu slučajnoga susreta umanjuje priliku za polaganjem mature te je jak indikator vjerojatnosti postizanja loših rezultata, što se može negativno odraziti na buduće fakultetsko obrazovanje mladih ljudi. Rezultati su statistički značajni s korekcijom za dob, spol, vjeru i zdravstveno stanje.

U kontekstu multivarijatne analize ne čini se da rizično zdravstveno ponašanje ima značajan učinak na učenički uspjeh na ispitu. Razlog tome može biti činjenica da u eksperimentalnih početničkih korisnika utjecaji štetnih tvari ne utječu izravno na školski uspjeh. 


\section{Rasprava}

Ovim smo istraživanjem pokazali da, želimo li pospješiti uspjeh koji učenici postižu na maturi, trebamo razmotriti kompleksnost čimbenika koji na njega utječu, a koji se odnose na socio-ekonomsku pozadinu, školski uspjeh u srednjoj školi, ali i na privatni život učenika. U zaključcima ćemo se usredotočiti na posljednju kategoriju čimbenika koji se odnose na spolno ponašanje učenika u pubertetu.

U svojoj studiji o spolnosti adolescenata Luster i Small (1994) dijele tinejdžere na tri tipa: visokorizični adolescenti (koji imaju nekoliko partnera i koji se rijetko ili nikad ne koriste kontracepcijom), niskorizični adolescenti (koji imaju jednog partnera i koji se uvijek koriste kontracepcijom) i apstinirajući ili spolno neaktivni adolescenti. Autori tvrde da upuštanje u riskantne spolne aktivnosti u navedenom razdoblju (od puberteta do rane odrasle dobi) može imati značajne posljedice na školski uspjeh.

Ovo je istraživanje također pokazalo da se spolno aktivni rumunjski tinejdžeri mogu podijeliti u barem dvije različite podskupine u kojima je rizik od pada na maturi povezan sa spolnim životom osobe. $U$ jednoj od te dvije skupine rizik od pada na maturi je nizak, a nju čine učenici koji svoj spolni život započinju kasnije, u vezi sa stalnim partnerom s kojim ostaju tijekom srednje škole. Druga je skupina rizičnija što se tiče mogućnosti pada na maturi, a obuhvaća učenike koji svoj spolni život započinju rano, s povremenim partnerima, koji često mijenjaju partnere i upuštaju se u kratke prolazne veze (Moore i Rosenthal, 1993).

Ta se kategorizacija može pokazati uspješnom pri izradi prevencijskih programa za prevenciju rizičnog zdravstvenog i spolnog ponašanja koje može utjecati na nastavak obrazovanja u mladih ljudi. Iako upis na fakultet nije jedini a ni najvažniji način za ostvarivanje prijelaza u odraslu dob, moramo priznati da u Rumunjskoj živi velik broj mladih ljudi koji još uvijek misle da je studentsko iskustvo važan korak prema sazrijevanju. Matura predstavlja prvu prepreku na putu za visoko obrazovanje (Montgomery i Côté, 2003, str. 151, 158). Naravno, prijelaz iz statusa srednjoškolca prema statusu studenta podrazumijeva polaganje mature. Stoga je ovo istraživanje kojemu je cilj bio ispitati ulogu rizičnog spolnog i zdravstvenog ponašanja u školskom uspjehu i uspjehu na maturi korisno i pravodobno.

Rezultati ove studije otvaraju nove mogućnosti u smislu istraživanja koja će pokušati odgovoriti na sljedeća i slična pitanja: Kakvu ulogu imaju spolni odnosi u profesionalnoj karijeri adolescenata? Imaju li spolna iskustva kakvu drugu ulogu osim one utjecajnih vršnjaka/osoba? Nude li spolna iskustva nešto jedinstveno u procesu socijalizacije? Nadamo se da će odgovori koje smo dali u ovome radu potaknuti buduće teorijske rasprave i objavljivanje drugih empirijskih studija o fascinantnom polju spolnosti adolescenata.

\section{Zaključci}

Moguće je da su od spomenutih odgovora važniji zaključci i pouke koje smo dobili i koje možemo upotrijebiti u izradi programa intervencije i prevencije rizičnog 
zdravstvenog ponašanja u budućnosti. Zalažemo se za odgoj i obrazovanje djece i adolescenata koje neće biti samo formalna aktivnost utemeljena na ocjenama, izvedbi i natjecanju, već na kurikulu sa snažnim osjećajem za zdravstveni odgoj. Takav kurikul treba biti usmjeren na osobnost kao cjelinu i pomagati adolescentima kako bi postali zdravi odrasli ljudi. Programi zdravstvenog odgoja trebaju obuhvaćati aspekte reproduktivnoga zdravlja i planiranja obitelji te trebaju biti više usredotočeni na široke i dugoročnije pristupe utemeljene na dinamici romantičnih odnosa (Finer i dr., 1999), dinamici društvenih mreža definiranih spolnim odnosima među osobama i dinamici uzoraka prenošenja spolnih bolesti unutar tih mreža (Aral, 1999) nego na puko prenošenje informacija o kontracepciji, prevenciji trudnoće i spolno prenosivih bolesti. Stoga temeljna jedinica budućih programa zdravstvenoga odgoja ne treba biti pojedinac, već par, a jedna od tema treba biti prakticiranje spolnih odnosa samo s jednim partnerom jer je utvrđeno da je to čimbenik stabilnosti i podrške u postizanju školskoga uspjeha, kao i čimbenik zaštite spolnoga ponašanja i prevencije rizičnog zdravstvenog ponašanja adolescenata.

\section{Bilješke}

Csaba László Dégi i Cristina Faludi radili su na prikupljanju podataka i njihovu unosu u SPSS bazu podataka, proveli su statističke analize te su napisali i revidirali tekst ovoga rada.

Za ovo su istraživanje dodijeljena sredstva Rumunjskog nacionalnog tijela za znanstvena istraživanja, CNCS - UEFISCDI, broj projekta PN-II-ID-PCE-2011-3-0543. 